\title{
ANALISIS DETERMINAN KEJADIAN BBLR DI RSUD DEMANG SEPULAU RAYA LAMPUNG TENGAH TAHUN 2019
}

\author{
Amanah Perdana Ningrum 1 , Aila Karyus ${ }^{2}$, Ferizal Masra ${ }^{3}$, Endang Budiarti ${ }^{4}$ \\ 1,2,3,4 Universitas Mitra Indonesia Bandar Lampung \\ Korespondensi Email : dian@umitra.ac.id
}

\begin{abstract}
ABSTRAK
Pendahuluan : BBLR adalah bayi baru lahir dengan berat badan lahir kurang dari 2500 gram.Dampak BBLR adalah anak berisiko sangat besar mengalami berbagai masalah saat ia tumbuh besar hingga dewasa. Risiko paling besar adalah stunting atau perawakan pendek. Metode: Jenis penelitian kuantitatif dalam penelitian ini adalah penelitian analitik dengan desain cross sectional, menggunakan data sekunder dari Instalasi rekam Medik rsud Demang Sepulau Raya Tahun 2019. Hasil : Angka kejadian BBLR sebesar 18,2 \%. Hasil analisis bivariat menunjukkan bahwa tidak ada hubungan yang signifikan antara usia ibu $(p=0,488)$, tingkat pendidikan $(p=0,865)$, riwayat penyakit $(p=0,127)$, riwayat prematur $(p=0,378)$, hidramnion $(p=0,086)$. Namun memiliki hubungan yang signifikan yaitu kehamilan ganda $(p=0,003, O R=12,440)$, dan anemia $(p=0,015$, $\mathrm{OR}=2,296)$ terhadap BBLR. Kehamilan ganda merupakan faktor yang paling dominan menyebabkan BBLR setelah dikontrol variabel lain. Kesimpulan: Perlu dikembangkan model deteksi dini BBLR di tingkat komunitas dengan merujuk pada faktor risiko yang ditemukan pada setiap unit pelayanan di Kabupaten Lampung Tengah
\end{abstract}

Kata Kunci: BBLR, determinan, angka kejadian

\section{Determinant Analysis of LBW Events in Demang Sepulau Raya Hospital in 2019}

\begin{abstract}
Introduction: is a newborn with a birth weight of less than 2500 grams. The impact of LBW is that children are at great risk of experiencing various problems as they grow up to adulthood. The biggest risk is stunting or short stature. Method: This type of quantitative research in this study is an analytic study with cross sectional design, using secondary data from the Medical Record Installation of Demang Sepulau Raya Hospital in 2019. Results: The incidence of $L B W$ was $18.2 \%$. The results of bivariate analysis showed that there was no significant relationship between maternal age $(p=0.488)$, education level $(p=0.865)$, history of disease $(p=0.127)$, premature history $(p=0.378)$, hydramnios $(p=0.086)$. But it has a significant relationship that is multiple pregnancy $(p=0.003, O R=12.440)$, and anemia ( $p=0.015, O R=2.296$ ) to $L B W$. Multiple pregnancy is the most dominant factor causing LBW after being controlled by other variables. Conclussion: It is necessary to develop an early detection model of $L B W$ at the community level by referring to the risk factors found in each service unit in Central Lampung District
\end{abstract}

Keywords: $L B W$, determinant, incidence rate

\section{PENDAHULUAN}

BBLR adalah bayi yang lahir dengan berat <2500 gram. Berat badan lahir merupakan indikator penting kesehatan bayi, faktor determinan kelangsungan hidup dan faktor untuk pertumbuhan fisik dan mental bayi di masa yang akan datang. Menurut hasil riset kesehatan dasar, prevalensi BBLR di Indonesia adalah sekitar 6,2 \%, data ini menunjukkan peningkatan dibanding tahun 2013 yakni sebanyak 5,7\%. Dari data tersebut $6,3 \%$ diantaranya terjadi didaerah pedesaan dan diketahui bahwa dilihat dari tingkat pendidikan kepala keluarga presentase terbesar adalah tidak sekolah yaitu sebesar 7,2\%. Dari data yang ada di Dinas Kesehatan Propinsi Lampung, pada tahun 2018 kematian neonatal di Propinsi Lampung terjadi sebanyak 169 kasus dan yang merupakan penyebab terbesar adalah disebabkan 
karena BBLR. Kabupaten dengan kematian neonatal dengan penyebab BBLR tertinggi terjadi di Kabupaten Lampung Tengah. Di RSUD Demang Sepulau Raya Lampung Tengah juga memiliki sistem pemantauan tumbuh kembang bagi balita dan juga ada stimulasi deteksi tumbuh kembang.

Dampak BBLR adalah anak berisiko sangat besar mengalami berbagai masalah saat ia tumbuh besar hingga dewasa. Risiko paling besar adalah stunting atau perawakan pendek.Anak dengan riwayat BBLR merupakan salah satu faktor yang potensial memengaruhi pertumbuhan anak.Penyebab utama kematian bayi di Kabupaten Lampung Tengah tahun 2018, sebagian besar terjadi karena BBLR yakni sebanyak 31 kasus $(32,29 \%)$, asfiksia sebanyak 20 kasus $(20,83 \%)$, kelainan bawaan sebanyak 15 kasus $(15,62 \%)$, karena sepsis sebanyak 5 kasus $(5,21 \%)$ dan karena sebab lain sebanyak 25 kasus (26,04\%).(Profil Kesehatan Lampung Tengah, 2018).

Berdasarkan pra survey yang dilakukan pada tanggal 14 Februari 2020 di RSUD Demang Sepulau Raya, didapatkan jumlah BBLR dan BBLSR di RSUD Demang Sepulau Raya tahun 2019 berjumlah 143 bayi atau sebesar 19,67\%. Jumlah ini menunjukkan peningkatan dibandingkan dengan jumlah BBLR dan BBLSR tahun 2018 yakni sebesar $17,48 \%$.

Hal ini disebabkan karena berbagai faktor, yaitu faktor biologis yang terdiri dari faktor maternal, kontaminasi lingkungan, kekurangan nutrisi, absorsi, pengawasan kesehatan perorangan dan faktor sosial ekonomi. (Profil Kesehatan Lampung Tengah, 2018).

\section{METODE}

Jenis penelitian yang digunakan pada penelitian ini kuantitatif yaitu penelitian yang didasarkan pada data kuantitatif. Jenis penelitian kuantitatif dalam penelitian ini adalah penelitian observasional analitik dengan desain cross sectional.

Populasi dalam penelitian ini adalah semua ibu bersalin dengan bayi lahir hidup di RSUD Demang Sepulau Raya yang ditimbang dan diketahui berat badan bayi lahirnya. Total bayi baru lahir di RSUD Demang Sepulau Raya tahun 2019 adalah sebanyak 727 ibu bersalin berdasarkan data dari rekam medis RSUD Demang Sepulau Raya. Dan sampael sebanyak 258 ibu bersalin. Penelitian ini telah dilakukan pada bulan Mei 2020. Namun data yang digunakan adalah data rekam medis pasien rawat inap tahun 2019.

Dalam penelitian ini data yang digunakan adalah data sekunder. Alat ukur yang digunakan adalah lembar observasi. Data sekunder diperoleh dari data rekam medik milik pasien di RSUD Demang Sepulau Raya Kabupaten Lampung Tengah yang menjadi sampel penelitian.

\section{HASIL}

Berdasarkan data yang diperoleh, terdapat 47 bayi atau sebesar 18,2 \% BBLR. Karakteristik responden pada penelitian ini meliputi: usia ibu, tingkat pendidikan, riwayat penyakit, anemia, riwayat prematur, kehamilan ganda dan hidramnion.

Tabel 1 menunjukkan bahwa, sebanyak 32,4\% atau 81 ibu bersalin dengan usia berisiko. Dari variabel tingkat pendidikan terdapat 173 ibu bersalin atau sebesar $67,1 \%$ memiliki tingkat pendidikan dengan kategori rendah. Variabel anemia didapatkan data sebanyak 116 ibu bersalin atau dengan presentase 44,9\% mengalami anemia. Sebanyak 239 ibu bersalin atau sebesar 92,6\% di RSUD Demang Sepulau Raya tahun 2019 tidak memiliki riwayat penyakit. Dalam variabel riwayat prematur, terdapat $7,8 \%$ memiliki riwayat pernah melahirkan prematur, yaitu sebanyak 20 ibu bersalin. Variabel kehamilan ganda didapatkan hasil, terdapat 7 ibu bersalin dengan kategori kehamilan ganda atau dengan presentase $2,7 \%$.Distribusi frekuensi hidramnion, terdapat 3 ibu bersalin dengan hidramnion atau sebesar $1,2 \%$ dari total responden sebanyak 258.

Tabel 2 secara statistik $p$ value yang didapat $<0,05$ yang menyatakan terdapat hubungan signifikan antara kehamilan 
ganda dan anemia terhadap kejadian BBLR. Tidak ada hubungan signifikan antara usia ibu, tingkat pendidikan, riwayat penyakit, riwayat prematur dan hidramnion

Tabel 1

Distribusi Frekuensi Beberapa Faktor Risiko BBLR

\begin{tabular}{clcc}
\hline & Variabel & $\mathrm{N}$ & $\%$ \\
\hline \multirow{2}{*}{ BBLR } & BBLR & 47 & $18,2 \%$ \\
\cline { 2 - 4 } & Tidak BBLR & 211 & $81.8 \%$ \\
\hline \multirow{2}{*}{ Usia Ibu } & Berisiko & 81 & $31,4 \%$ \\
\cline { 2 - 4 } & Tidak Berisiko & 177 & $68,6 \%$ \\
\hline Tingkat & Rendah & 173 & $67,1 \%$ \\
\cline { 2 - 4 } Pendidikan & Tinggi & 85 & $32,9 \%$ \\
\hline Riwayat & Memiliki & 19 & $7,4 \%$ \\
Penyakit & Tidak Memiliki & 239 & $92,6 \%$ \\
\hline \multirow{2}{*}{ Anemia } & Anemia & 116 & $44,9 \%$ \\
\cline { 2 - 4 } & Tidak Anemia & 142 & $55,1 \%$ \\
\hline Riwayat & Pernah & 20 & $7,8 \%$ \\
\cline { 2 - 4 } Prematur & Tidak Pernah & 238 & $92,2 \%$ \\
\hline Kehamilan & Kehamilan Ganda & 7 & $2,7 \%$ \\
\cline { 2 - 4 } Ganda & Tidak Kehamilan Ganda & 251 & $97,3 \%$ \\
\hline \multirow{2}{*}{ Hidramnion } & Hidramnion & 3 & $1,2 \%$ \\
\cline { 2 - 4 } & Tidak Hidramnion & 255 & $98,8 \%$ \\
\hline
\end{tabular}

Tabel 2

Analisis Bivariat Determinan Kejadian BBLR

\begin{tabular}{|c|c|c|c|c|c|c|c|}
\hline \multirow{3}{*}{ Usia Ibu } & \multicolumn{4}{|c|}{ BBLR } & & & \multirow{3}{*}{$P$-Value } \\
\hline & \multicolumn{2}{|c|}{ BBLR } & \multicolumn{2}{|c|}{ Tidak BBLR } & \multicolumn{2}{|c|}{ TOTAL } & \\
\hline & $\mathrm{n}$ & $\%$ & $\mathrm{n}$ & $\%$ & $\mathrm{n}$ & $\%$ & \\
\hline Berisiko & 17 & $21 \%$ & 64 & $79 \%$ & 81 & $100 \%$ & \multirow{2}{*}{0,488} \\
\hline Tidak Berisiko & 30 & $16,9 \%$ & 147 & $83,1 \%$ & 177 & $100 \%$ & \\
\hline \multicolumn{7}{|l|}{ Tingkat Pendidikan } & \multirow{3}{*}{0.865} \\
\hline Rendah & 31 & $17,9 \%$ & 142 & $82,1 \%$ & 173 & $100 \%$ & \\
\hline Tinggi & 16 & $18,8 \%$ & 69 & $81,2 \%$ & 85 & $100 \%$ & \\
\hline \multicolumn{7}{|l|}{ Riwayat Penyakit } & \multirow[b]{3}{*}{0,127} \\
\hline Memiliki Riwayat Penyakit & 6 & $31,6 \%$ & 13 & $68,4 \%$ & 19 & $100 \%$ & \\
\hline $\begin{array}{l}\text { Tidak Memiliki Riwayat } \\
\text { Penyakit }\end{array}$ & 41 & $17,2 \%$ & 198 & $82,8 \%$ & 239 & $100 \%$ & \\
\hline \multicolumn{7}{|l|}{ Anemia } & \multirow{3}{*}{$\begin{array}{c}0,015 \\
\text { OR }=2,296\end{array}$} \\
\hline Anemia & 29 & $25 \%$ & 87 & $75 \%$ & 116 & $100 \%$ & \\
\hline Tidak Anemia & 18 & $12,7 \%$ & 124 & $87,3 \%$ & 142 & $100 \%$ & \\
\hline Riwayat Prematur & & & & & & & 0,378 \\
\hline \multicolumn{7}{|l|}{ Pernah Melahirkan } & \\
\hline Prematur & 5 & $25 \%$ & 15 & $75 \%$ & 20 & $100 \%$ & \\
\hline \multicolumn{7}{|l|}{ Tidak Pernah Melahirkan } & \\
\hline Prematur & 42 & $17,6 \%$ & 196 & $82,4 \%$ & 238 & $100 \%$ & \\
\hline \multicolumn{7}{|l|}{ Kehamilan Ganda } & \multirow[t]{3}{*}{$\begin{array}{c}0,003 \\
\text { OR }=12,440\end{array}$} \\
\hline IYA & 5 & $71,4 \%$ & 2 & $28,6 \%$ & 7 & $100 \%$ & \\
\hline TIDAK & 42 & $16,7 \%$ & 209 & $83,3 \%$ & 251 & $100 \%$ & \\
\hline
\end{tabular}


Hidramnion 0,086

Hidramnion $2 \quad 66,7 \%$ $\begin{array}{llllll}45 & 17,6 \% & 210 & 82,4 \% & 255 & 100 \%\end{array}$

Tidak Hidramnion

Tabel 3

Model Awal dan Akhir Analisis Multivariat Determinan Kejadian BBLR

\begin{tabular}{lrccc}
\hline \multicolumn{1}{c}{ Variabel } & \multicolumn{3}{c}{ Model awal } & Model akhir \\
& $P_{\text {_value }}$ & $\mathrm{OR}(95 \% \mathrm{Cl})$ & $P_{\text {_value }}$ & OR(95\%Cl $)$ \\
\hline Usia ibu & 0.415 & $1.340(0.663-2.705)$ & & \\
\hline $\begin{array}{l}\text { Kehamilan } \\
\text { Ganda }\end{array}$ & 0.002 & $14.923(2.697-82.564)$ & 0.004 & $12.293(2.238-67.507)$ \\
\hline Anemia & 0.019 & $2.259(1.145-4.458)$ & 0.015 & $2.283(1.173-4.446)$ \\
\hline Hidramnion & 0.064 & $10.509(0.871-126.824)$ & & \\
\hline $\begin{array}{l}\text { Riwayat } \\
\text { Penyakit }\end{array}$ & 0.067 & $2.695(0.934-7.774)$ & & \\
\hline Constant & 0.004 & 0.008 & 0.271 & \\
\hline
\end{tabular}

Variabel - variabel kandidat yang memenuhi kriteria kandidat model multivariat adalah variabel yang bermaksan secara statistik $(p<0,05)$ dan variabel yang memiliki nilai $p<0,25$ meliputi kehamilan ganda, anemia, riwayat prematur, hidramnion. Namun variabel usia dimasukkan karena berpengaruh terhadap BBLR.

Tabel 3 untuk analisis multivariat dilakukan beberapa tahapan yang pertama yaitu seleksi bivariat untuk mengetahui variabel mana yang akan dimasukan kedalam permodelan multivariat. Selanjutnya pemeriksaan counfounding (perubahan OR > $10 \%$ ) dengan mengeluarkan variabel yang $p$ valuenya $\geq 0,05$ secara bertahap dari $p$ value yang besar.Dari hasil analisis model terakhir diketahui bahwa variabel yang paling dominan adalah variabel kehamilan ganda. Dengan p-value 0,003 dan $O R=12,293$. Yang berarti bahwa kehamilan ganda memiliki peluang 12,293 kali lebih besar untuk melahirkan bayi dibanding dengan kehamilan ganda.

\section{PEMBAHASAN \\ Usia lbu}

Pada penelitian ini ada 17 bayi atau $21 \%$ lahir dalam keadaan BBLR. diperoleh bahwa $p$ value $=0,488$ yang berarti $p$ value $>0,05$ maka ada hubungan antara usia ibu dengan kejadian BBLR di RSUD Demang Sepulau Raya tahun
2019.Penelitian ini sejalan dengan penelitian yang dilakukan oleh Karlina Sulistian (2014) dalam Faktor risiko kejadian bayi berat lahir rendah (BBLR) di wilayah kerja Puskesmas kota Tangerang Selatan tahun 2012- 2014, bahwa umur ibu <20 dan >35 tahun bukan merupakan faktor risiko kejadian BBLR. Hal ini menunjukan bahwa umur ibu $<20$ dan $>35$ tahun tidak berisiko terhadap kejadian BBLR di Wilayah Kerja Puskesmas Kota Tangerang Selatan Tahun 2012-2014.

Berdasarkan hasil penelitian ini perlu diinformasikan kepada ibu hamil mengingat bahwa faktor umur memegang peranan penting terhadap derajat kesehatan dan kesejahteraannya serta bayi, maka sebaiknya merencanakan kehamilan di usia reproduksi aman yaitu 20- 35 tahun (Julina, 2017)

\section{Tingkat Pendidikan}

Pada penelitian ini ada 31 diantaranya melahirkan bayi dengan BBLR. Diperoleh bahwa $p$ value $=0,865$ yang berarti $p$ value $>0,05$ maka tidak ada hubungan antara tingkat pendidikan ibu dengan kejadian BBLR di RSUD Demang Sepulau Raya tahun 2019.Penelitian ini tidak sejalan dengan penelitian yang dilakukan oleh Intan Kumalasari (2014) tentang Faktor Resiko Dan Angka Kejadian Berat Badan Lahir Rendah (BBLR) Di RSUP DR. Mohammad 
Hoesin Palembang Tahun 2014 yang menunjukkan ada hubungan bermakna tingkat pendidikan dengan BBLR terjadi pada ibu dengan tingkat pendidikan rendah dari pada tingkat pendidikan tinggi, begitu juga dengan hasil mutivariat $(p=0,044)$. Dalam penelitian ini pendidikan ibu memang tidak ada hubungan dengan kejadian BBLR. Ibu dan keterbatasan mengkonsumsi makanan yang bergizi selama hamil karena kejadian BBLR lebih terkait pada faktor patofisiologi, kualitas plasenta, air ketuban, pola konsumsi dan diet.

\section{Riwayat Penyakit}

Ada 19 bayi, 6 bayi $(31,6 \%)$ mengalami BBLR. Diperoleh bahwa $p$ value $=0,127$ yang berarti $p$ value $>0,05$ maka tidak ada hubungan antara riwayat penyakit dengan kejadian BBLR di RSUD Demang Sepulau Raya tahun 2019.Penelitian ini sejalan dengan penelitian yang dilakukan oleh Karlina Sulistian (2014) dalam Faktor risiko kejadian bayi berat lahir rendah (BBLR) di wilayah kerja Puskesmas kota Tangerang Selatan tahun 2012- 2014, bahwa tidak dapat dianalisis bahwa riwayat penyakit berpengaruh terhadap BBLR.Meskipun demikian melihat masih adanya ibu bersalin yang memiliki riwayat kesehatan misalnya darah tinggi, anemia, hidramnion, kehamilan ganda, penyakit jantung bawaan dan lain-lain perlu direkomendasikan kepada ibu hamil agar diupayakan melakukan deteksi dini dalam hal pencegahan komplikasi yaitu dapat melalui kunjungan ANC rutin serta disarankan kepada tenaga kesehatan dapat memberikan informasi melalui konseling kepada ibu dan keluarga mengenai penyakit selama kehamilan.

\section{Anemia}

Ada 25\% atau 29 diantaranya melahirkan bayi dengan BBLR. Setelah dilakukan uji chi-square diperoleh bahwa $p$ value $=0,015$ yang berarti $p$ value $<0,05$ maka ada hubungan antara anemia dengan kejadian BBLR di RSUD Demang Sepulau Raya tahun 2019. Dengan OR 2,296, berarti ibu melahirkan yang tidak
( $p=0,000)$, dengan resiko 1,870 kali lebih besar

yang berpendidikan rendah sulit untuk menerima inovasi dan sebagian besar kurang mengetahui pentingnya perawatan pra kelahiran dan mempunyai keterbatasan mendapatkan pelayanan antenatal yang adekuat mengalami anemia memiliki peluang 2,296 lebih besar untuk bisa melahirkan bayi dengan tidak BBLR dibandingkan dengan ibu anemia. Hasil penelitian ini sejalan dengan hasil penelitian yang dilakukan oleh Intan Kumalasari (2014) tentang Faktor Resiko Dan Angka Kejadian Berat Badan Lahir Rendah (BBLR) Di Rsup DR. Mohammad Hoesin Palembang Tahun 2014 dengan $(p=0,000)$ menunjukkan hubungan yang bermakna antara kadar $\mathrm{Hb}$ dengan kejadian BBLR. Ibu hamil dengan kadar $\mathrm{Hb}<11$ berpeluang 1,861 kali lebih besar melahirkan BBLR dibandingkan kadar $\mathrm{Hb}$ $>11$.

Menurut pendapat peneliti dan teori yang ada, bahwa masih banyak ibu hamil kurang dalam konsumsi tablet Fe. Selain itu, asupan nutrisi yang mengandung zat besi juga perlu ditingkatkan dalam masa kehamilan. Pemantauan kadar haemoglobin ibu hamil perlu terus dilakukan yaitu dengan cek $\mathrm{Hb}$ setiap kali melakukan kunjungan ANC.

\section{Riwayat Prematur Pada Saat Ini}

Terdapat $7,8 \%$ memiliki riwayat pernah melahirkan prematur, yaitu sebanyak 20 ibu bersalin. Diperoleh bahwa $p$ value $=0,378$ yang berarti $p$ value $>0,05$ maka tidak ada hubungan antara riwayat prematur dengan kejadian BBLR di RSUD Demang Sepulau Raya tahun 2019.Penelitian ini sejalan dengan Nelly (2016) dalam Faktor Resiko Pada Kejadian Berat Badan Lahir Rendah (BBLR) bahwa tidak adanya hubungan yang signifikan antara riwayat persalinan BBLR dengan kejadian berat badan lahir rendah (BBLR). Hal ini selain untuk mencegah terjadinya kelahiran prematur berulang, juga untuk mencegah terjadinya BBLR. Prematur dan BBLR bisa dikatakan sangat berkaitan. Adanya risiko umur 
kehamilan terhadap kejadian BBLR disebabkan karena secara biologis berat badan bayi semakin bertambah sesuai dengan umur kehamilan.

\section{Kehamilan Ganda}

Terdapat 7 ibu bersalin dengan kategori kehamilan ganda atau dengan presentase 2,7\%.Diperoleh bahwa $p$ value $=0,003$ yang berarti $p$ value $<0,05$ maka ada hubungan antara kehamilan ganda dengan kejadian BBLR di RSUD Demang Sepulau Raya tahun 2019. Dengan OR 12,440 , berarti ibu bersalin dengan tidak kehamilan ganda memiliki peluang 12,440 kali melahirkan bayi tidak BBLR dibandingkan dengan ibu dengan kehamilan ganda.Hasil penelitian ini sejalan dengan hasil penelitian yang dilakukan oleh Intan Kumalasari (2014) tentang Faktor Resiko Dan Angka Kejadian Berat Badan Lahir Rendah (BBLR) Di Rsup DR. Mohammad Hoesin Palembang Tahun 2014 yang menyatakan bahwa ada hubungan yang bermakna antara kehamilan ganda dengan kejadian BBLR. Dengan $p=0,000$ dan $O R=19,070$. Pemantauan saat ANC menjadi sangat penting dengan adanya janin yang lebih dari satu sehingga meningkatkan risiko terhadap komplikasi kehamilan. Hal ini disebabkan beban ibu semakin berat dengan mengandung lebih dari satu janin dalam kandungannya. Pemantauan perkiraan berat badan janin dibutuhkan agar bayi yang kelak lahir adalah bayi dalam keadaan sehat. (Nurwahyuni, 2017).

\section{Hidramnion}

Terdapat 3 ibu bersalin dengan hidramnion atau sebesar $1,2 \%$. diperoleh bahwa $p$ value $=0,086$ yang berarti $p$ value $>0,05$ maka tidak ada hubungan antara hidramnion dengan kejadian BBLR di RSUD Demang Sepulau Raya tahun 2019. Hal ini tidak sejalan dengan penelitian Ani (2014) dalam Pengaruh Penyakit Penyerta Kehamilan dan Kehamilan Ganda dengan Kejadian Bayi Berat Lahir Rendah di RSUD Arifin Achmad Provinsi Riau yang menyatakan bahwa ada hubungan antara hidramnion dan kejadian BBLR ( $p$ value
$=0,0001) \cdot$ Kunjungan ANC sesuai dengan anjuran akan memperkecil terjadi risiko komplikasi yang ada. Karena anamnesa dan pemeriksaan dalam ANC dapat memberikan solusi sehingga akan menekan terjadinya masalah. Informasi yang diberikan selama ANC akan membantu ibu mendapatkan pengetahuan seputar kelamilan dan kelahiran. Namun disisi lain ada pula tingkat pendidikan yang rendah yang dapat berpengaruh terhadap informasi yang diterima ibu selama kehamilan yang akan menyebabkan masalah selama kehamilan dan melahirkan.

\section{SIMPULAN DAN SARAN Simpulan}

Tidak ada hubungan antara determinan usia, tingkat pendidikan, riwayat penyakit, riwayat prematur dan hidramnion. Namun ada hubungan signifikan antara anemia dengan BBLR dengan $O R=2,296$ dan kehamilan ganda dengan BBLR dengan OR=12,440. Kehamilan ganda merupakan determinan paling dominan setelah melalui uji interaksi dengan $\mathrm{OR}=13,530$.

Saran

Diharapkan dinas kesehatan bersama dengan RSUD Demang Sepulau Raya melakukan monitoring secara berkelanjutan terkait program PONED untuk pemantauan terhadap faktor risiko terhadap BBLLR. Meningkatkan pelaksanaan program PKRS sesuai dengan SPO yang ada. Diharapkan tenaga kesehatan juga mampu mendetksi dini segala komplikasi dan tidak terlambat dalam melakukan rujukan dan dapat berkalaborasi dengan dokter spesialis kebidanan dan kandungan dalam upaya pencegahanBBLR.

Diharapkan peneliti selanjutnya dapat meneliti variabel lain misalnya : berat badan ibu, LILA dll yang merupakan keterbatasan penelitian.

\section{KONFLIK KEPENTINGAN}

Tidak terdapat konflik kepentingan yang ditemukan pada penelian ini 


\section{KEPUSTAKAAN}

Amelia Sylvia Wafda Nur, (2019), Asuhan Kebidanan Kasus Kompleks Maternal \& Neonatal. Yogyakarta : Pustaka Baru Press, 2019

Ambarwati Eny Retna, Rismintari Y Sriati, (2012), Asuhan Kebidanan Komunitas. Yogyakarta : Nuha Medika, 2011

Chomariah Nurul, (2019), Seputar Kehamilan . Jakarta : PT Elex Media, 2019

Deswitaa (2015) Pengalaman lbu dalam Merawat Bayi dengan Prematur dan Berat Badan Lahir Rendah tahun 2015https://www.ejurnal.com/2015/12/pengalaman-ibudalam-merawat-bayi.html diakses 12 Februari 2020

Julina Br. Sembiring, Debby Pratiwi, Aprilian Sarumaha (2017) Hubungan usia, paritas dan usia kehamilan dengan BBLR di RSU Mitra Medika Medan tahun 2017 http://ejournal.helvetia.ac.id/index.php /jbk/article/view/4110/159diakses 23 Februari 2020 https://www.lampost.co/berita-empatkabupaten-kasus-tertinggistunting.html

Husamah, (2012), Kamus Penyakit pada Manusia. Yogyakarta : ANDI OFFSET, 2012

Kristiyanasari, Weni, (2010), Gizi lbu Hamil . Yogyakarta : Nuha Medika, 2010

Mitayani, (2011), Asuhan Keperawatan Maternitas . Jakarta : Salemba Medika, 2011

Neneng Siti Latifah, Nurul Isnaini, Meilia Syafitri (2013)Hubungan Bayi Berat Lahir Rendah (Bblr) Dengan Kematian Neonatal Di Rsud. Dr. H. Abdul Moeloek Bandar Lampung Tahun 2013https://www.ejurnal.com/2016/12/hubungan-bayiberat-lahir-rendah bblr 14.html diakses 15 Februari 2020

Notoatmodjo, Prof.Dr.Soekidjo, (2007), Kesehatan Masyarakat IImu dan Seni . Jakarta : PT Rineka Cipta, 2007
Nugroho Taufan, (2012), Patologi Kebidanan . Yogyakarta : Nuha Medika, 2012

Nurwahyuni (2017), Hubungan antara antenatal care dengan upaya melakukan upaya pencegahan bahaya dalam kehamilan. Universitas Muhammadiyah Semarang.

Prima Maulana Cahyo Nugroho, Lilia Dewiyanti, Afiana Rohmani (2015)Tingkat Keparahan Asfiksia Neonatorum Pada Bayi Berat Lahir Rendah (Bblr) Tahun 2015https://www.ejurnal.com/2016/11/tingkatkeparahan-asfiksia-neonatorum.html diakses 12 Februari 2020

Sugeng, Weni Kristiyanasari, (2011), Asuhan Keperawatan Neonatus dan Anak. Yogyakarta : Nuha Medika, 2011

Sumarah, Yani Widyastuti dan Nining Wiyati, (2009), Perawatan lbu Bersalin (Asuhan Kebidanan Pada Ibu Bersalin). Yogyakarta : Penerbit Fitramaya, 2009

Uki Nengsih, Noviyanti, Dedi S. Djamhuri,(2015) Hubungan Riwayat Kelahiran Berat Bayi Lahir Rendah dengan Pertumbuhan Anak Usia Balita Di Kabupaten Bandung pada tahun 2015https://www.ejurnal.com/2018/07/hubunganriwayat-kelahiran-berat-bayi.html diakses 5 Februari 2020

Uliyah, Musrifatul dan Hidayat, A. Aziz Alimul (2006), Keterampilan Dasar Praktek Klinik Kebidanan. Jakarta : Salemba Medika, 2006

Wibowo, Adik (2014), Metodologi Penelitian Praktis Bidang Kesehatan . PT RajaGrafindo Persada : Jakarta

Winarsih, (2018), Pengantar IImu Gizi dalam Kebidanan. Pusaka Baru Press : Yogyakarta 